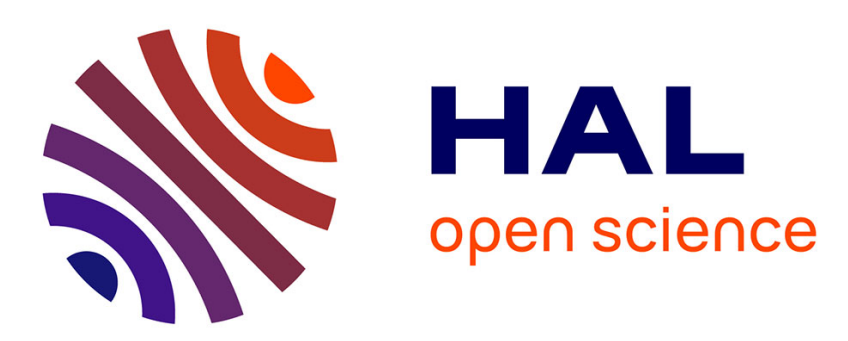

\title{
Adult neural stem cell cycling in vivo requires thyroid hormone and its alpha receptor.
}

Gregory Lemkine, A. Raji, Gladis Alfama, Nathalie Turque, Zahra Hassani, Olinda Alegria-Prevot, Jaques Samarut, Giovanni Levi, Barbara A. Demeneix

\section{- To cite this version:}

Gregory Lemkine, A. Raji, Gladis Alfama, Nathalie Turque, Zahra Hassani, et al.. Adult neural stem cell cycling in vivo requires thyroid hormone and its alpha receptor.. FEBS Journal, 2005, 19, pp.863-865. hal-00090188

\section{HAL Id: hal-00090188 \\ https://hal.science/hal-00090188}

Submitted on 28 Aug 2006

HAL is a multi-disciplinary open access archive for the deposit and dissemination of scientific research documents, whether they are published or not. The documents may come from teaching and research institutions in France or abroad, or from public or private research centers.
L'archive ouverte pluridisciplinaire HAL, est destinée au dépôt et à la diffusion de documents scientifiques de niveau recherche, publiés ou non, émanant des établissements d'enseignement et de recherche français ou étrangers, des laboratoires publics ou privés. 
The FASEB Journal express article 10.1096/fj.04-2916fje. Published online February 23, 2005.

\title{
Adult neural stem cell cycling in vivo requires thyroid hormone and its alpha receptor
}

\author{
G. F. Lemkine,* A. Raji,* G. Alfama, ${ }^{*}$ N. Turque, ${ }^{*}$ Z. Hassani, ${ }^{*}$ O. Alegria-Prévot, ${ }^{*}$ \\ J. Samarut, ${ }^{\dagger}$ G. Levi, ${ }^{*}$ and B. A. Demeneix*
}

*UMR CNRS 5166, Evolution des Régulations Endocriniennes, Muséum National d'Histoire Naturelle, 75231 Paris Cedex 05 ; and ${ }^{\dagger}$ UMR CNRS 5665, Laboratoire de Biologie Moléculaire et Cellulaire, Ecole Normale Supérieure de Lyon, 69364 Lyon Cedex 07, France

Correspondence: Barbara Dememeix, UMR CNRS 5166, Evolution des Régulations Endocriniennes, Muséum National d'Histoire Naturelle, 75231 Paris Cedex 05, France. E-mail: demeneix@mnhn.fr

\section{ABSTRACT}

Thyroid hormones (TH) are essential for brain development. However, information on if and how this key endocrine factor affects adult neurogenesis is fragmentary. We thus investigated the effects of TH on proliferation and apoptosis of stem cells in the subventricular zone (SVZ), as well as on migration of transgene-tagged neuroblasts out of the stem cell niche. Hypothyroidism significantly reduced all three of these processes, inhibiting generation of new cells. To determine the mechanisms relaying $\mathrm{TH}$ action in the SVZ, we analyzed which receptor was implicated and whether the effects were played out directly at the level of the stem cell population. The $\alpha \mathrm{TH}$ receptor (TR $\alpha$ ), but not TR $\beta$, was found to be expressed in nestin positive progenitor cells of the SVZ. Further, use of TR $\alpha$ mutant mice showed TR $\alpha$ to be required to maintain full proliferative activity. Finally, a direct $\mathrm{TH}$ transcriptional effect, not mediated through other cell populations, was revealed by targeted gene transfer to stem cells in vivo. Indeed, TH directly modulated transcription from the $c$-myc promoter reporter construct containing a functional TH response element containing TRE but not from a mutated TRE sequence. We conclude that liganded-TR $\alpha$ is critical for neurogenesis in the adult mammalian brain.

Key words: subventricular zone • NSC • TH

U nderstanding the genetic regulation of neural stem cell (NSC) maintenance, division, and differentiation is a central problem in NSC biology. The identification of subventricular astrocytes as NSCs in the subventricular zone (SVZ) of the adult rodent brain contributed to the confirmation of the existence of a neurogenic niche in this region (1). Although relatively quiescent and slow dividing, the NSC population residing in this site gives rise to rapidly dividing neural progenitors, which in turn generate neural precursors that have the ability to generate both neurons and glia. However, most cells emerging from the SVZ undergo apoptosis (2), while many of the remaining cells migrate to form new interneurons in the 
olfactory lobe (3). Some cells may also generate glial cells in the corpus callosum (4). To exploit the therapeutic potential of endogenous stem cells, knowledge of the intrinsic and extrinsic mechanisms affecting NSC population size and expansion is needed. However, few studies have addressed endocrine control of NSC function, particularly in vivo (5).

The thyroid hormones (TH) are essential for brain development in all vertebrates (6). The main secreted form of $\mathrm{TH}$ is thyroxine $\left(\mathrm{T}_{4}\right)$, which is converted to the biologically more active form triiodothyronine $\left(\mathrm{T}_{3}\right)$, in peripheral tissues. In each species studied, TH levels are highest during the period of most rapid brain growth and development, which in humans occurs during the first 2 yr of postnatal life. Lack of TH in early development causes severe neurological damage and results in cretinism in man (7). At the cellular level, TH action on specific cells and at specific phases of development is known to be a major factor in regulating the timing of proliferation and differentiation decisions in a number of neural and nonneural cellular populations including retinal progenitors $(8-10)$, oligodendrocyte precursors $(11,12)$, and erythroid precursors $(13)$. Thus, although it is known that transient exposure of NSCs to TH in vitro initiates a stable switch to a glial fate through a direct, instructive mechanism (14), the potential effects of TH on NSC proliferation and survival have yet to be characterized in their in vivo context.

\section{MATERIALS AND METHODS}

\section{Treatment of animals, in vivo transfection, and luciferase assay}

All animal studies were conducted according to the principles and procedures described in Guidelines for Care and Use of Experimental Animals.

To induce hypothyroidism or hyperthyroidism, female OF1 mice (Janvier, Le Genest St. Isle, France) were given, respectively, an iodine deficient food containing 0.15\% 6-n-propyl-2thiouracil (PTU from Harlan Teklad, Madison, WI) or a solution of $\mathrm{T}_{3} 1.5 \mu \mathrm{M}$ (Sigma, SaintQuentin Fallavier, France) diluted in the drinking water both for 2 wk. To confirm their thyroid status, $\mathrm{T}_{3}$ levels in plasma were determined using Amerlex- $\mathrm{T}_{3}$ RIA-kit (Trinity Biotech, Wicklow, Ireland). $T_{3}$ values in PTU-treated, control, and hyperthyroid animals were $19.6 \pm 1.9$, $49.4 \pm 2.5$, and $415.5 \pm 35 \mathrm{ng} / \mathrm{dl}$, respectively (means $\pm \mathrm{SE}, n=6$ for each group). For evaluating $\mathrm{T}_{3}$ effects on reporter gene expression, animals were injected intraperitonealy with $10 \mu \mathrm{g}$ of $\mathrm{T}_{3} / 30 \mathrm{~g}$ body wt (in $9 \%$ saline). Controls received saline ( $9 \%$ ) injections. Luciferase activity was measured in tissue homogenates as described previously (15).

\section{Animals}

$T R \beta^{{ }^{\prime-}}$ mice (16), lacking $T R \beta 1$ and $T R \beta 2$, and $T R \alpha^{0 / 0}$ mice (17), lacking $T R \alpha 1, T R a 2, T R \Delta \alpha 1$, and $T R \Delta \alpha 2$, were maintained on a $129 / \mathrm{Sv}$ strain. The DNA construct for gene targeting was engineered to associate the disruption of the $T R$ gene with an in-frame insertion of the lac-Z reporter gene. Wild-type 129/Sv mice were purchased from Charles River Laboratories (L'Arbresle, France). 


\section{Plasmid preparation, formulation of polyethylenimine/DNA complexes, and stereotaxic injection}

The c-myc promoter fragment (murine origin $[-1141 /+516]$ a generous gift from Dr. Garcia-Silva from the laboratory of Dr. Aranda, Instituto de Investigaciones Biomedicas "Alberto Sols," Universidad Autonoma of Madrid, Spain) was inserted in pG12 basic vector from Promega (Madison, WI) upstream of the coding sequence of firefly (Photinus pyralis) luciferase. The same promoter fragment was mutated in the TRE using the QuickChange XL site-directed mutagenesis kit from (Stratagene) and the primer 5'-

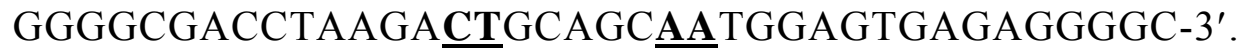

Endotoxin-free DNA was prepared using affinity columns (Genomed, Research Triangle Park, NC). Plasmid DNA (1 $\mu \mathrm{g}$ per animal) was diluted in 5\% glucose to the chosen concentration, complexed with $22 \mathrm{kDa}$ linear polyethylenimine (PEI; ratio of 6 PEI nitrogens per DNA phosphate, ref 18), and then vortexed. One single injection $(5 \mu 1)$ was performed into either right or left lateral ventricle $(0.2 \mathrm{~mm}$ posterior to bregma line, $1.1 \mathrm{~mm}$ lateral, and $2.2 \mathrm{~mm}$ deep from the pial surface) of 2-mo-old OF-1 mice (Janvier) anaesthetized with $60 \mathrm{mg} / \mathrm{kg}$ pentobarbital (Sanofi, Paris, France). As previously shown (19), this mode of nonviral plasmid delivery results in preferential transfection of adult NSCs and their immediate progeny in the SVZ. Therefore, it provides an ideal system to monitor effects of $\mathrm{TH}$ on gene expression after PEI-mediated transfection.

To follow migration in the rostral migratory stream (RMS), we performed intraventricular injections of PEI complexed plasmid $p C M V-L a c Z$ to genetically label NSCs and their progeny (19). One week after injections, saggital vibratome sections $(80 \mu \mathrm{m})$ were prepared and stained for $\beta$-galactosidase (19). Transgene expressing cells that had migrated from at least $100 \mu \mathrm{m}$ from the ventricle were counted.

\section{Histological techniques}

Mice were deeply anesthetized with $130 \mathrm{mg} / \mathrm{kg}$ pentobarbital (Sanofi) and then sequentially perfused $(3 \mathrm{ml} / \mathrm{min})$ with saline solution $(0.9 \% \mathrm{NaCl})$ and $2 \%$ paraformaldehyde (PFA). Brains were dissected and postfixed in $2 \%$ PFA. Immunohistological reactions were performed on cryostat sections $(10 \mu \mathrm{m})$.

Bromodeoxyuridine (BrdU; Fluka, Saint-Quentin Fallavier, France) was administered in the drinking water $(1 \mathrm{mg} / \mathrm{ml})$ for $2 \mathrm{wk}$ or by intraperitoneal injection $(150 \mathrm{mg} / \mathrm{kg}) 3$ days or $2 \mathrm{~h}$ before death.

The 2 wk administration allows labeling of the relatively quiescent population including the slow-dividing stem cells. The 3 days pulse of BrdU labels more rapidly proliferating cells. In normal conditions, the 3 days chase allows these cells to dilute BrdU, whereas the relatively quiescent cells retain the BrdU label (20-22). Two hours of BrdU treatment labels actively cycling cells.

BrdU labeling was done using a monoclonal mouse anti-BrdU antibody (Dako, Trappes, France) at a 1:50 dilution in PBS containing 1\% bovine serum albumin (BSA). Antigenic sites were 
unmasked by two microwave cycles ( $5 \mathrm{~min}$ at $750 \mathrm{~W}$, in $10 \mathrm{mM}$ citrate buffer, $\mathrm{pH}$ 6). To minimize endogenous reactivity with monoclonal antibody, we made use of the Dako ARK peroxidase conjugated revelation system (Dako, Trappes, France).

Polyclonal rabbit antibody anti-phosphorylated histone H3 (Upstate, Lake Placid, NY) was applied at a 1:200 dilution. Polyclonal rabbit antibody anti-Ki67 (Novocastra Laboratories, Newcastle upon Tyne, UK) was applied at a 1:1000 dilution. Polyclonal rabbit antibody antiactivated caspase-3 (BD PharMingen, Franklin Lakes, NJ) was applied at a 1:200 dilution.

For TH receptor detection, we used polyclonal antibodies directed against the TR $\alpha 1$ isoform (1:10, overnight, $4^{\circ} \mathrm{C}$ ) and TR $\beta$ isoform (see ref $23,1: 50$ overnight $4^{\circ} \mathrm{C}$ ) on cryostat sections $(10$ $\mu \mathrm{m})$. The TR $\alpha 1$ antibody was raised against a $\mathrm{C}$-terminal peptide and affinity-purified with the same peptide (a gift from Dr. Plateroti, Ecole Normale Supérieure Lyon). Antigenic sites were previously unmasked by two microwave cycles ( $5 \mathrm{~min}$ at $750 \mathrm{~W}$, in $10 \mathrm{mM}$ citrate buffer, pH 6).

The primary monoclonal antibody anti-nestin (BD PharMingen) was applied at 1:500 dilution. Triple labeling with either TR $\alpha$ or TR $\beta$ (green) on DAPI $(1 \mu \mathrm{g} / \mathrm{ml})$ stained sections (blue nuclei) was performed revealing anti-nestin with secondary anti-mouse IgG1 antibody conjugated with Cy3 (red) from Sigma. Nestin labeling on $\beta$-galactosidase stained cryostat sections (10 $\mu \mathrm{m})$ of TR null mice was revealed using Dako ARK (Dako).

We used secondary antibody biotinylated anti-rabbit (1:800, $1 \mathrm{~h}$, room temperature) that was revealed using extravidin-Cy3 (1:5000, $1 \mathrm{~h}$, room temperature), both from Sigma. We used secondary antibody anti-rabbit peroxidase conjugated at 1:200, $1 \mathrm{~h}$, room temperature (Dako).

Semithin sections of TR null mice were prepared from vibratome sections previously stained with a $2 \mathrm{mM}$ BluoGal (Life Technologies, Cergy Pontoise, France) solution as described previously (24).

\section{Statistical analysis of results}

Each set of cell counts (BrdU, PhosH3, Ki67, and caspase-3 positive cells) were performed on sections taken from 0.7 to $1.2 \mathrm{~mm}$ anterior to bregma and carried out double-blindly by two observers.

In vivo gene transfer and cell counts results are means \pm SE per group. After ANOVA analysis where appropriate, Kruskal-Wallis test was used to analyze differences between groups. Differences were considered significant at $P<0.05$. In all cases, typical experiments are shown. Each experiment was carried out with $n \geq 6$, repeated at least three times, and provided the same results.

\section{RESULTS}

\section{Hypothyroidism reduces NSC proliferation}

We modified the thyroid status of adult mice and examined DNA synthesis and proliferation in the SVZ. We used two distinct protocols to label differentially BrdU-incorportating cells. First, to label dividing neural progenitors, BrdU was given punctually for 3 days before death. An 
alternative protocol in which 2 wk BrdU exposure was followed by a 3 day BrdU-free chase period was used so as to label slowly proliferating cells. In this protocol, the chase period will result in loss, by dilution, of the BrdU signal from the rapidly dividing progenitor population but not from the slow-dividing cells or cells that have exited the cell cycle. Induction of hypothyroidism by propylthiouracil (PTU) treatment (see Materials and Methods) increased numbers of cells in the SVZ-incorporating BrdU in both protocols (Fig. 1A and $\underline{B}$ ). Close examination of the labeled cells revealed that hypothyroidism actually resulted in increased intensity of the BrdU signal (Fig. 1A, lower panels) in individual cells. This observation suggests that once acquired, the BrdU labeling is not diluted by successive cell divisions, indicating that cells are either not completing the cell cycle and/or not undergoing further divisions. We therefore chose to examine the actual mitotic state of the cells.

To quantify proliferation, we used the active cell cycle marker Ki67 that labels cells in $\mathrm{G}_{1}, \mathrm{~S}, \mathrm{G}_{2}$, and $\mathrm{M}$ phases (25) and phosphorylated histone $\mathrm{H} 3$ (PhosH3) (26-28). PhosH3 increases in $\mathrm{G}_{2}$ and is maximal in $M$ phase and is rapidly lost as cells enter $G_{1}(27,29)$. Hypothyroidism significantly reduced PhosH3-positive cells in the SVZ (Fig. 2A-C, $P<0.001$ ) and halved the number of Ki67 positive cells in the SVZ (Fig. 2D). These apparently contradictory results from BrdU and cell cycle markers studies are reconcilable if, in hypothyroidism, cells accumulate BrdU but do not re-enter the cell cycle.

Taken with the data on proliferation, we infer that the increased BrdU labeling seen in hypothyroid animals is indicative of increased number of cells that have synthesized DNA but have exited the cell cycle. Thus, we further characterized the cell cycling state of resting progenitors in the SVZ. We performed double labeling between Ki67 (actively cycling cells) and BrdU incorporation after a 3 day BrdU treatment (Fig. 2E). The proportion of cells that have synthesized DNA but do not re-enter the cell cycle increases in hypothyroid mice, indicating that absence of TH results in accumulation of resting progenitors in the SVZ (Fig. 2F).

\section{Hypothyroidism limits NSC migration}

To test whether TH affects the migratory capacity of NSC progeny, we used an in vivo gene transfer protocol that specifically labels NSC by expression of an exogenous reporter gene. This technique exploits PEI, which specifically targets plasmid DNA to the SVZ stem cell and neuroprogenitor population in vivo (19). Stereotaxic delivery of PEI-condensed DNA encoding lac- $Z$ to the SVZ resulted in $\beta$-galactosidase expression in cells in the SVZ and in the RMS (Fig. $\underline{3 A}$ and $\underline{B})$. Hypothyroidism halved $(P<0.05)$ the numbers of lac- $Z$ expressing cells in the RMS (Fig. 3B).

Apoptosis is the fate of most progenitors arising from NSC division in the SVZ (2). To investigate whether thyroid status modifies apoptosis in the SVZ, we followed activated caspase3 , one of the ultimate players in the apoptosis program (ref 30 and Fig. $3 D$ and E). Hypothyroidism halved $(P<0.05)$ the number of caspase-3 positive cells in this region (Fig. $3 E$ ). Reduction of apoptosis could also contribute to increased numbers of BrdU-labeled cells accumulating in the SVZ during hypothyroidism. 


\section{TH regulates NSC proliferation through the $\mathrm{TR} \alpha$ receptor}

The data so far indicate that $\mathrm{TH}$ is required for NSC to pass through mitosis and enter the differentiation or apoptosis programs. The question then arises of the mechanisms underlying these actions and whether they are direct. TH regulates gene transcription through $\mathrm{TH}$ receptors that are transcription factors belonging to the steroid hormone/retinoic acid receptor superfamily (31). In vertebrates, two genes encode TH receptors, $T R \alpha$ and $T R \beta$ (32). Immunocytochemistry with TH receptor specific antibodies (see Materials and Methods) showed TR $\alpha 1$, but not TR $\beta$, to be expressed in the nestin-expressing cells of the SVZ ( $\underline{\text { Fig. } 4 A}$ and $\underline{B})$. TR $\alpha^{0 / 0}$ mice and TR $\beta^{{ }^{\prime-}}$ mice lack all isoforms produced from the $T R \alpha$ or the $T R \beta$ loci, respectively (33). To examine further TR expression in the SVZ, we used $\beta$-galactosidase as a marker for TR-expressing cells in TR mutant mice (Fig. $4 C$ and $\underline{D}$ ) and homozygous null mice (Fig. $4 E$ and $\underline{F}$ ). $\beta$-galactosidase staining reflecting expression from the TR $\alpha$ promoter was strong in the SVZ of TR $\alpha$ mutant mice (Fig. $4 C, \underline{E}$, and $\underline{G}$ ). In contrast, in $\operatorname{TR} \beta$ mutant mice no $\beta$-galactosidase staining could be detected suggesting low or undetectable levels of TR $\beta$ expression in this area (Fig. $4 D$, $\underline{F}$, and $\underline{H})$. $\beta$-Galactosidase staining was carried out together with nestin immunochemistry to label the SVZ NSCs and progenitor cells in homozygous animals. Noticeably, nestin expression in the $T R \alpha^{0 / 0}$ mice was markedly reduced (compare Fig. $4 I$ and $\underline{J}$ ) differing from the usual pattern recapitulated in $T R \beta^{-1}$ mice, where nestin-positive extensions reach out perpendicularly from the SVZ toward the striatum.

Given the specific expression of TR $\alpha$ in the SVZ, we followed DNA synthesis and mitosis in $\mathrm{TR} \alpha^{0 / 0}$ mice, maintained under euthyroid conditions. BrdU accumulation after a 3 day treatment was significantly increased in $T R \alpha^{0 / 0}$ mice compared with wild-type counterparts (Fig. $\left.4 K-M\right)$. Inversely, PhosH3-positive cells were halved in $T R \alpha^{0 / 0}$ mice (Fig. $\left.4 N\right)$. Thus, TR $\alpha$ absence inhibits progression of NSC through the cell cycle and suggests a role for TR $\alpha$ in mediating $\mathrm{TH}$ effects on NSC cycling.

\section{TH directly regulates gene expression and proliferation in the NSC population}

Expression of the TR $\alpha$ gene in the SVZ strongly argues for a direct effect of $\mathrm{TH}$ on transcriptional regulation in these stem cells. To assess whether this is the case, we used PEImediated gene delivery to introduce into the stem cells a construction containing $1.6 \mathrm{~kb}$ of the mouse c-myc promoter cloned upstream of the luciferase gene. Hypothyroidism doubled transcription from the c-myc promoter, whereas transcription was repressed in animals treated with $\mathrm{T}_{3}$ for 2 wk with expression levels not different from controls (Fig. 5A). In a second protocol, hypothyroid mice were transfected with $c$-myc-luc and immediately exposed to $\mathrm{T}_{3}$ for 3 days. Again, in this short $T_{3}$ exposure experimental paradigm $T_{3}$ significantly reduced transcription from the $c-m y c$ promoter in vivo (Fig. $5 B$ ). Thus, both long-term (2 wk) and shortterm $(36 \mathrm{~h}) \mathrm{T}_{3}$ treatment reduce transcription from the $c$-myc promoter in adult SVZ NSCs and their progeny. This TH effect was direct as it was lost if the TRE in the $c$-myc promoter was mutated (Fig. 5B).

The above findings suggest a direct action of $\mathrm{TH}$ on stem cell activity and should implicate a rapid response to $\mathrm{TH}$. To estimate the delay of action of $\mathrm{TH}$ on proliferation, we went back to a BrdU incorporation protocol. However, this time the protocol differed from those used in the 
initial experiments in that it was a short, $2 \mathrm{~h}$ pulse of BrdU as opposed to a long treatment ( $2 \mathrm{wk}$ ) followed or not by a chase. We applied this $2 \mathrm{~h}$ BrdU incorporation protocol on hypothyroid mice that were injected either with $\mathrm{T}_{3}$ solution for $10 \mathrm{~h}$ before death (i.e., $8 \mathrm{~h}$ before $\mathrm{BrdU}$ treatment) or with saline control solution (Fig. 5C and $\underline{D}$ ). With this short pulse of BrdU that only labels cells in S phase, we observed significantly more positive cells in euthyroid mice than in hypothyroid mice (Fig. 5E). The rapid treatment with $\mathrm{T}_{3}$ fully restored the number of cells in $\mathrm{S}$ phase to the euthyroid levels (Fig. 5E), again arguing for a direct effect of $\mathrm{TH}$ on proliferation.

\section{DISCUSSION}

Thyroid hormone has long been known to regulate neurodevelopment in all vertebrates. In humans, if hypothyroidism occurs early in development (in the fetus or neonate), it causes mental retardation and profound deafness. Much work on the complex roles of $\mathrm{TH}$ in neurodevelopment has shown that TH must act within a critical window of developmental time, beyond which hormone replacement cannot recover normal function. Moreover, $\mathrm{TH}$ actions are widespread, affecting many structures both during early development and later as a maturation factor (34).

Given these key actions of TH during brain development, we chose to analyze whether thyroid status affected adult neurogenesis. A first result was that lack of TH severely hampers the proliferative potential of the stem cell population in the SVZ of the adult mouse brain. We used a number of different protocols to follow the kinetics of DNA synthesis (BrdU accumulation) and to quantify the number of cells actually undergoing mitosis at any given time in different thyroid states. We show that lack of TH reduces mitotic figures in the SVZ and that a short pulse of TH revives the process. This rapid effect of TH on mitotic activity within hours in the SVZ suggests that $\mathrm{TH}$ is acting directly on the stem cell population.

A second set of data arguing for a direct effect of TH includes the demonstration of TR $\alpha$ expression in the SVZ. These observations exploited deconvolution confocal microscopy on wild-type animals and LacZ expression in animals in which this gene had been used as an inframe insertion to disrupt the expression of the endogenous $T R$ gene. Further, use of mutant mice lacking the TR $\alpha$ receptor showed that absence of this receptor reproduces the effect of hypothyroidism on mitotic capacity of SVZ NSCs. Two genes encode the related TR $\alpha$ and TR $\beta$ receptors across all vertebrate species, suggesting that both genes are essential for $\mathrm{TH}$ action. Alternative splicing and differential use of promoters produces a variety of isoforms from each TR gene, including TR $\alpha 1, T R \alpha 2$, TR $\beta 1$, and TR $\beta 2$. In TR $\alpha^{0 / 0}$ mutant mice not only TR $\alpha 1$ is absent but also TR $\alpha 2$ and some truncated C-terminal products. However, TR $\alpha 2$ and the truncated forms are unable to bind $\mathrm{TH}$ and, therefore, TR $\alpha 1$ is the only bona fide $\mathrm{TH}$ receptor that can mediate $T_{3}$ neurogenic action in the SVZ. TR $\alpha 1$ presence in the SVZ is revealed by immunodetection with the specific anti-TR $\alpha 1$ antibody. In early neurodevelopment, TR $\alpha 1$ is widely expressed, whereas TR $\beta$ variants are more restricted (34). The role of TR $\alpha$ receptor in neurogenesis is underscored by our findings that TR $\alpha$ continues to be expressed in one of the few parts of the CNS that maintains a proliferative potential in the adult and that lack of the gene products hampers proliferation to the same extent as lack of TH. The data also corroborate previous results showing a role for TR $\alpha$ in regulating mitosis in chick embryo neuroblasts (35) and the finding that an EST similar to TR $\alpha$ was found in a genomic expression profile of NSC 
(36). Another intriguing finding in the $\mathrm{TR} \alpha^{0 / 0}$ mice is the disruption of nestin expression patterns, also observed by Morte et al. (37) using another line of mutant mice lacking specifically TR $\alpha 1$. Furthermore, apoptosis, known to be the major fate of NSCs progeny in the SVZ and which is probably closely linked to cell cycle to balance proliferation (22), is also affected by hypothyroidism. Taken together, these results indicate that not only proliferation but the entire organization of the stem cell niche is affected by lack of $\mathrm{TH}$.

A third line of argument for a direct role of TH on NSC biology comes from the finding that TH regulates transcription from a promoter sequence delivered into this population. In these in vivo gene transfer experiments, we exploited an approach that had previously been proven to target gene transfer to the stem cell population (19) in which we used electron-microscopy to reveal triple colocalization of exogenous reporter gene products with mitotic and stem cell markers, specifically within stem cells in the adult SVZ. This targeted gene transfer technique thus privileges delivery of exogenous genes specifically to the stem cell population. This targeting is probably due to their proliferative capacity (38) and/or the expression in the stem cells niche of proteoglycans that have been identified as receptors for cationic polyplex delivery (39) and that are present on neural precursor cells (40). Using this technique, we find that injecting $\mathrm{T}_{3}$ into hypothyroid mice represses transcription from a c-myc promoter-driven luciferase construct introduced into the stem cell population. This transcriptional effect must be direct, as it is lost when the TH response element in the promoter is mutated. The data are consistent with results showing that $\mathrm{TH}$-induced differentiation of neuroblastoma cells is preceded by a rapid decrease of $c-m y c$ gene expression through a negative $\mathrm{T}_{3}$ responsive element in the promoter (41). Further, the finding that transcription from the c-myc promoter is up-regulated in NSC of hypothyroid mice could indicate that endogenous $c-m y c$ is regulated by TH the NSC. Indeed, given the fact that c-myc is known to be a $T_{3}$ dependent gene and that $c-m y c$ regulation is related to cell cycle control, it is tempting to speculate that endogenous $c-m y c$ may be a key target gene relaying the effects of $T_{3}$ on neural progenitors cycle.

These in vivo findings show that TH intervenes in the earliest stages of stem cell biology, i.e., in the decision to initiate and undergo proliferation. In the SVZ, TH deficiency results in abnormal accumulation of BrdU positive cells, indicative of failure to re-enter the cell cycle on the one hand and of reduced apoptosis on the other. Similarly, the absence of TR $\alpha$, normally expressed in the SVZ, also blocked cell cycle progression. These data suggest that, besides the wellestablished multiple roles of $\mathrm{TH}$ in early neurogenesis, $\mathrm{TH}$ is an essential component of the endocrine environment that activates NSC growth, migration, and apoptosis. Further, the results demonstrate that the negative effects of $\mathrm{TH}$ on mitotic capacity have repercussions on the number of cells migrating through the RMS. Recent work identifies NSCs in the adult human brain, which remain relatively quiescent in vivo (42), suggesting the importance of the cellular environment to activate stem cells. Endocrine factors such as TH could be key factors to reveal regenerative potential of endogenous or grafted stem cells.

Taken together these findings could have far-reaching clinical implications particularly in an aging population that is prone to hypothyroidism. Indeed, hypothyroidism is associated with loss of sense of smell in rodents (43) and more importantly, in humans with cognitive decline and depression $(44,45)$. Furthermore, as active neurogenesis is required to see the behavioral effects of anti-depressants (46), it is tempting to speculate that the link between hypothyroidism and depression could implicate reduced neurogenesis. 


\section{ACKNOWLEDGMENTS}

We thank Dr. R. Denver for insightful comments; Dr. Perez-Juste for the basic c-myc-luciferase construct; Dr. M. Plateroti for the TR antibodies; Dr. M. Geze and the CEMIM service for deconvolution microscopy; K. Palmier, P. Normandie, and F. Genies for help with some experiments; and E. Legoff, G. Rancillac, and C. Forgeron for animal care. This work was supported by the AFM, INSERM (ACI Stem Cells and ATC Vieillissement) and EU Commission (contract QL 93 CT 200000 844).

\section{REFERENCES}

1. Doetsch, F., Caille, I., Lim, D. A., Garcia-Verdugo, J. M., and Alvarez-Buylla, A. (1999) Subventricular zone astrocytes are neural stem cells in the adult mammalian brain. Cell 97, 703-716

2. Morshead, C. M., and van der Kooy, D. (1992) Postmitotic death is the fate of constitutively proliferating cells in the subependymal layer of the adult mouse brain. J. Neurosci. 12, 249256

3. Saghatelyan, A., de Chevigny, A., Schachner, M., and Lledo, P. M. (2004) Tenascin-R mediates activity-dependent recruitment of neuroblasts in the adult mouse forebrain. Nat. Neurosci. 7, 347-356

4. Nait-Oumesmar, B., Decker, L., Lachapelle, F., Avellana-Adalid, V., Bachelin, C., and Van Evercooren, A. B. (1999) Progenitor cells of the adult mouse subventricular zone proliferate, migrate and differentiate into oligodendrocytes after demyelination. Eur. J. Neurosci. 11, 4357-4366

5. Shingo, T., Gregg, C., Enwere, E., Fujikawa, H., Hassam, R., Geary, C., Cross, J. C., and Weiss, S. (2003) Pregnancy-stimulated neurogenesis in the adult female forebrain mediated by prolactin. Science 299, 117-120

6. Forrest, D. (2002) Twists in the tail-change-of-function mutations in thyroid hormone receptors. Endocrinology 143, 2466-2468

7. Porterfield, S. P., and Hendrich, C. E. (1993) The role of thyroid hormones in prenatal and neonatal neurological development-current perspectives. Endocr. Rev. 14, 94-106

8. Jacobson, M., and Rao, M. S. (2004) Developmental Neurobiology, Kluwer Academic/Plenum, New York

9. Harpavat, S., and Cepko, C. L. (2003) Thyroid hormone and retinal development: an emerging field. Thyroid 13, 1013-1019

10. Marsh-Armstrong, N., Huang, H., Remo, B. F., Liu, T. T., and Brown, D. D. (1999) Asymmetric growth and development of the Xenopus laevis retina during metamorphosis is controlled by type III deiodinase. Neuron 24, 871-878 
11. Tokumoto, Y. M., Tang, D. G., and Raff, M. C. (2001) Two molecularly distinct intracellular pathways to oligodendrocyte differentiation: role of a p53 family protein. EMBO J. 20, 5261-5268

12. Billon, N., Tokumoto, Y., Forrest, D., and Raff, M. (2001) Role of thyroid hormone receptors in timing oligodendrocyte differentiation. Dev. Biol. 235, 110-120

13. Bauer, A., Mikulits, W., Lagger, G., Stengl, G., Brosch, G., and Beug, H. (1998) The thyroid hormone receptor functions as a ligand-operated developmental switch between proliferation and differentiation of erythroid progenitors. EMBO J. 17, 4291-4303

14. Johe, K. K., Hazel, T. G., Muller, T., Dugich-Djordjevic, M. M., and McKay, R. D. (1996) Single factors direct the differentiation of stem cells from the fetal and adult central nervous system. Genes Dev. 10, 3129-3140

15. Lemkine, G. F., Goula, D., Becker, N., Paleari, L., Levi, G., and Demeneix, B. A. (1999) Optimisation of polyethylenimine-based gene delivery to mouse brain. J. Drug Target. 7, 305-312

16. Gauthier, K., Chassande, O., Plateroti, M., Roux, J. P., Legrand, C., Pain, B., Rousset, B., Weiss, R., Trouillas, J., and Samarut, J. (1999) Different functions for the thyroid hormone receptors TRalpha and TRbeta in the control of thyroid hormone production and post-natal development. EMBO J. 18, 623-631

17. Macchia, P. E., Takeuchi, Y., Kawai, T., Cua, K., Gauthier, K., Chassande, O., Seo, H., Hayashi, Y., Samarut, J., Murata, Y., et al. (2001) Increased sensitivity to thyroid hormone in mice with complete deficiency of thyroid hormone receptor alpha. Proc. Natl. Acad. Sci. USA 98, 349-354

18. Abdallah, B., Sachs, L., Hourdry, J., Wegnez, M., Denis, H., Demeneix, B., and Mazabraud, A. (1996) Thyroid hormone regulation of germ cell-specific EF-1 alpha expression during metamorphosis of Xenopus laevis. Int. J. Dev. Biol. 40, 507-514

19. Lemkine, G. F., Mantero, S., Migne, C., Raji, A., Goula, D., Normandie, P., Levi, G., and Demeneix, B. A. (2002) Preferential transfection of adult mouse neural stem cells and their immediate progeny in vivo with polyethylenimine. Mol. Cell. Neurosci. 19, 165-174

20. Shi, Y., Chichung Lie, D., Taupin, P., Nakashima, K., Ray, J., Yu, R. T., Gage, F. H., and Evans, R. M. (2004) Expression and function of orphan nuclear receptor TLX in adult neural stem cells. Nature 427, 78-83

21. Johansson, C. B., Momma, S., Clarke, D. L., Risling, M., Lendahl, U., and Frisen, J. (1999) Identification of a neural stem cell in the adult mammalian central nervous system. Cell 96, $25-34$

22. Doetsch, F., Verdugo, J. M., Caille, I., Alvarez-Buylla, A., Chao, M. V., and CasacciaBonnefil, P. (2002) Lack of the cell-cycle inhibitor p27Kip1 results in selective increase of transit-amplifying cells for adult neurogenesis. J. Neurosci. 22, 2255-2264 
23. Baas, D., Fressinaud, C., Ittel, M. E., Reeber, A., Dalencon, D., Puymirat, J., and Sarlieve, L. L. (1994) Expression of thyroid hormone receptor isoforms in rat oligodendrocyte cultures. Effect of 3,5,3'-triiodo-L-thyronine. Neurosci. Lett. 176, 47-51

24. Lemkine, G. F., Mantero, S., Migne, C., Raji, A., Goula, D., Normandie, P., Levi, G., and Demeneix, B. A. (2002) Preferential transfection of adult mouse neural stem cells and their immediate progeny in vivo with polyethylenimine. Mol. Cell Neurosci. 19, 165-174

25. Schluter, C., Duchrow, M., Wohlenberg, C., Becker, M. H., Key, G., Flad, H. D., and Gerdes, J. (1993) The cell proliferation-associated antigen of antibody Ki-67: a very large, ubiquitous nuclear protein with numerous repeated elements, representing a new kind of cell cycle-maintaining proteins. J. Cell Biol. 123, 513-522

26. Ajiro, K., Yoda, K., Utsumi, K., and Nishikawa, Y. (1996) Alteration of cell cycledependent histone phosphorylations by okadaic acid. Induction of mitosis-specific H3 phosphorylation and chromatin condensation in mammalian interphase cells. J. Biol. Chem. 271, 13197-13201

27. Hendzel, M. J., Wei, Y., Mancini, M. A., Van Hooser, A., Ranalli, T., Brinkley, B. R., Bazett-Jones, D. P., and Allis, C. D. (1997) Mitosis-specific phosphorylation of histone H3 initiates primarily within pericentromeric heterochromatin during G2 and spreads in an ordered fashion coincident with mitotic chromosome condensation. Chromosoma 106, 348360

28. Chadee, D. N., Hendzel, M. J., Tylipski, C. P., Allis, C. D., Bazett-Jones, D. P., Wright, J. A., and Davie, J. R. (1999) Increased Ser-10 phosphorylation of histone H3 in mitogenstimulated and oncogene-transformed mouse fibroblasts. J. Biol. Chem. 274, 24914-24920

29. Crosio, C., Fimia, G. M., Loury, R., Kimura, M., Okano, Y., Zhou, H., Sen, S., Allis, C. D., and Sassone-Corsi, P. (2002) Mitotic phosphorylation of histone H3: spatio-temporal regulation by mammalian Aurora kinases. Mol. Cell. Biol. 22, 874-885

30. Roth, K. A., Kuan, C., Haydar, T. F., D'Sa-Eipper, C., Shindler, K. S., Zheng, T. S., Kuida, K., Flavell, R. A., and Rakic, P. (2000) Epistatic and independent functions of caspase-3 and Bcl-X(L) in developmental programmed cell death. Proc. Natl. Acad. Sci. USA 97, 466-471

31. Mangelsdorf, D. J., and Evans, R. M. (1995) The RXR heterodimers and orphan receptors. Cell 83, 841-850

32. Forrest, D., Munoz, A., Raynoschek, C., Vennstrom, B., and Beug, H. (1990) Requirement for the C-terminal domain of the $\mathrm{V}$-erbA oncogene protein for biological function and transcriptional repression. Oncogene 5, 309-316

33. Flamant, F., and Samarut, J. (2003) Thyroid hormone receptors: lessons from knockout and knock-in mutant mice. Trends Endocrinol. Metab. 14, 85-90

34. Forrest, D., Reh, T. A., and Rusch, A. (2002) Neurodevelopmental control by thyroid hormone receptors. Curr. Opin. Neurobiol. 12, 49-56 
35. Lezoualc'h, F., Seugnet, I., Monnier, A. L., Ghysdael, J., Behr, J. P., and Demeneix, B. A. (1995) Inhibition of neurogenic precursor proliferation by antisense alpha thyroid hormone receptor oligonucleotides. J. Biol. Chem. 270, 12100-12108

36. D'Amour, K. A., and Gage, F. H. (2003) Genetic and functional differences between multipotent neural and pluripotent embryonic stem cells. Proc. Natl. Acad. Sci. USA 100, Suppl. 1, 11866-11872

37. Morte, B., Manzano, J., Scanlan, T. S., Vennstrom, B., and Bernal, J. (2004) Aberrant maturation of astrocytes in thyroid hormone receptor alpha 1 knockout mice reveals an interplay between thyroid hormone receptor isoforms. Endocrinology 145, 1386-1391

38. Brunner, S., Sauer, T., Carotta, S., Cotten, M., Saltik, M., and Wagner, E. (2000) Cell cycle dependence of gene transfer by lipoplex, polyplex and recombinant adenovirus. Gene Ther. 7, 401-407

39. Labat-Moleur, F., Steffan, A. M., Brisson, C., Perron, H., Feugeas, O., Furstenberger, P., Oberling, F., Brambilla, E., and Behr, J. P. (1996) An electron microscopy study into the mechanism of gene transfer with lipopolyamines. Gene Ther. 3, 1010-1017

40. Brickman, Y. G., Ford, M. D., Small, D. H., Bartlett, P. F., and Nurcombe, V. (1995) Heparan sulfates mediate the binding of basic fibroblast growth factor to a specific receptor on neural precursor cells. J. Biol. Chem. 270, 24941-24948

41. Perez-Juste, G., Garcia-Silva, S., and Aranda, A. (2000) An element in the region responsible for premature termination of transcription mediates repression of c-myc gene expression by thyroid hormone in neuroblastoma cells. J. Biol. Chem. 275, 1307-1314

42. Sanai, N., Tramontin, A. D., Quinones-Hinojosa, A., Barbaro, N. M., Gupta, N., Kunwar, S., Lawton, M. T., McDermott, M. W., Parsa, A. T., Manuel-Garcia Verdugo, J., et al. (2004) Unique astrocyte ribbon in adult human brain contains neural stem cells but lacks chain migration. Nature 427, 740-744

43. Beard, M. D., and Mackay-Sim, A. (1987) Loss of sense of smell in adult, hypothyroid mice. Brain Res. 433, 181-189

44. Samuels, M. H. (1998) Subclinical thyroid disease in the elderly. Thyroid 8, 803-813

45. Davis, J. D., Stern, R. A., and Flashman, L. A. (2003) Cognitive and neuropsychiatric aspects of subclinical hypothyroidism: significance in the elderly. Curr. Psychiatry Rep. 5, 384-390

46. Santarelli, L., Saxe, M., Gross, C., Surget, A., Battaglia, F., Dulawa, S., Weisstaub, N., Lee, J., Duman, R., Arancio, O., et al. (2003) Requirement of hippocampal neurogenesis for the behavioral effects of antidepressants. Science 301, 805-809

Received August 27, 2004; accepted December 27, 2004. 
Fig. 1

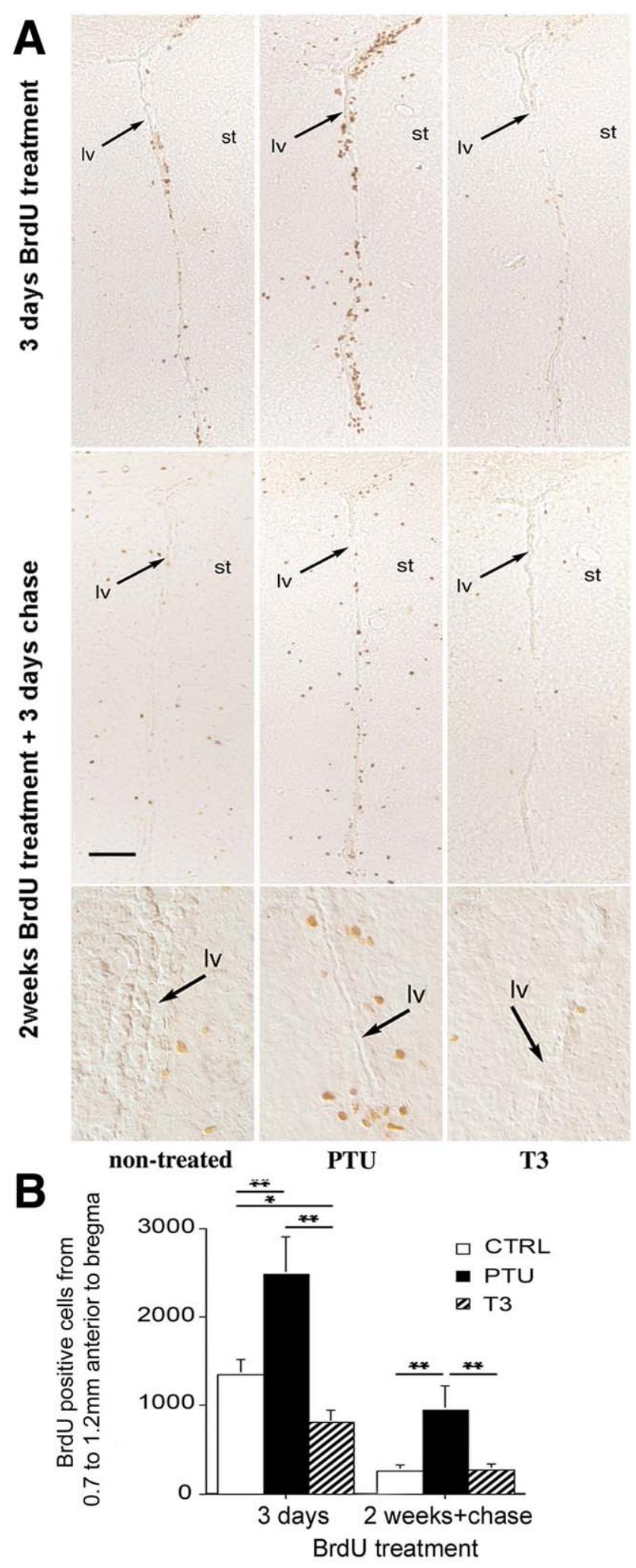

Figure 1. Hypothyroidism affects BrdU incorporation in SVZ of adult mouse brain. $A$ ) Immunohistology of BrdU positive cells (dark-brown) in ventricular region of nontreated (left panels), hypothyroid (central), or hyperthyroid (right) adult mouse brains. Hypothyroidism increases BrdU incorporation after a 3 day BrdU pulse (upper panels) and after a 2 wk treatment/3 day chase protocol (middle panels) compared with $\mathrm{T}_{3}$ treatment or controls. At higher magnification (lower panels), BrdU labeling in the second protocol appears more intense in hypothyroid animals than in hyperthyroid or nontreated controls. Upper and middle panels: bar: $200 \mu \mathrm{m}$; lower panels: bar: $40 \mu \mathrm{m}$. lv, lateral ventricle. $\boldsymbol{B}$ ) Quantification of BrdU labeling. In this and the following histograms, means \pm SE are given; $n=3-6$ animals per group. 
Fig. 2

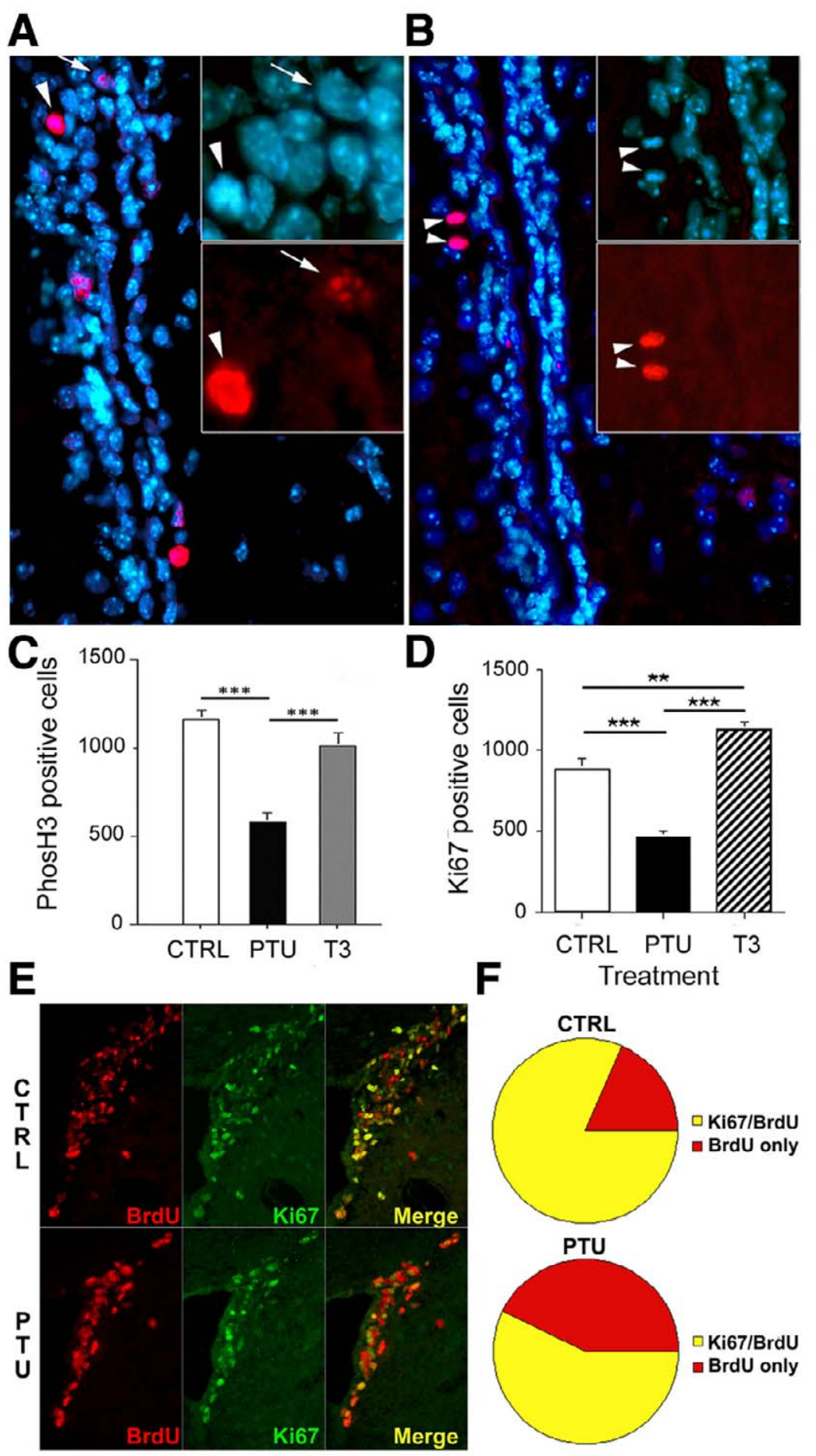

Figure 2. Hypothyroidism reduces the number of mitotic cells in the SVZ of adult mouse brain: in hypothyroid mice BrdU positive cells do not re-enter the cell cycle. $\boldsymbol{A}, \boldsymbol{B}) \mathrm{PhosH} 3$ immunodetection (red) with Hoechst 33258 nuclear staining (blue) in control $(\boldsymbol{A})$ or hypothyroid animals $(\boldsymbol{B})$. Bar: $\boldsymbol{A}$ and $\boldsymbol{D}: 50 \mu \mathrm{m}$; inserts: $20 \mu \mathrm{m}$. $\boldsymbol{C}$ ) Hypothyroidism reduces numbers of phosH3 positive cells compared with control or hyperthyroid animals $(* * * P<0.001)$. $\boldsymbol{D})$ Hypothyroidism halves Ki67 positive cells compared with controls or hyperthyroid animals $(* * * P<0.001)$. Each experiment was repeated 3 times giving similar results. E) Immunohistology of BrdU-positive cells (red), Ki67 (green) and double labeling (merged in yellow) in the ventricular region of nontreated (upper panels), or hypothyroid (lower panels) adult mouse brains. F) Hypothyroidism increases the ratio of BrdU positive/Ki67 negative cells after a 3 day BrdU pulse compared with controls. Cells were counted from 0.7 to $1.2 \mathrm{~mm}$ anterior to bregma for each animal using dichroic microscopy. 
Fig. 3
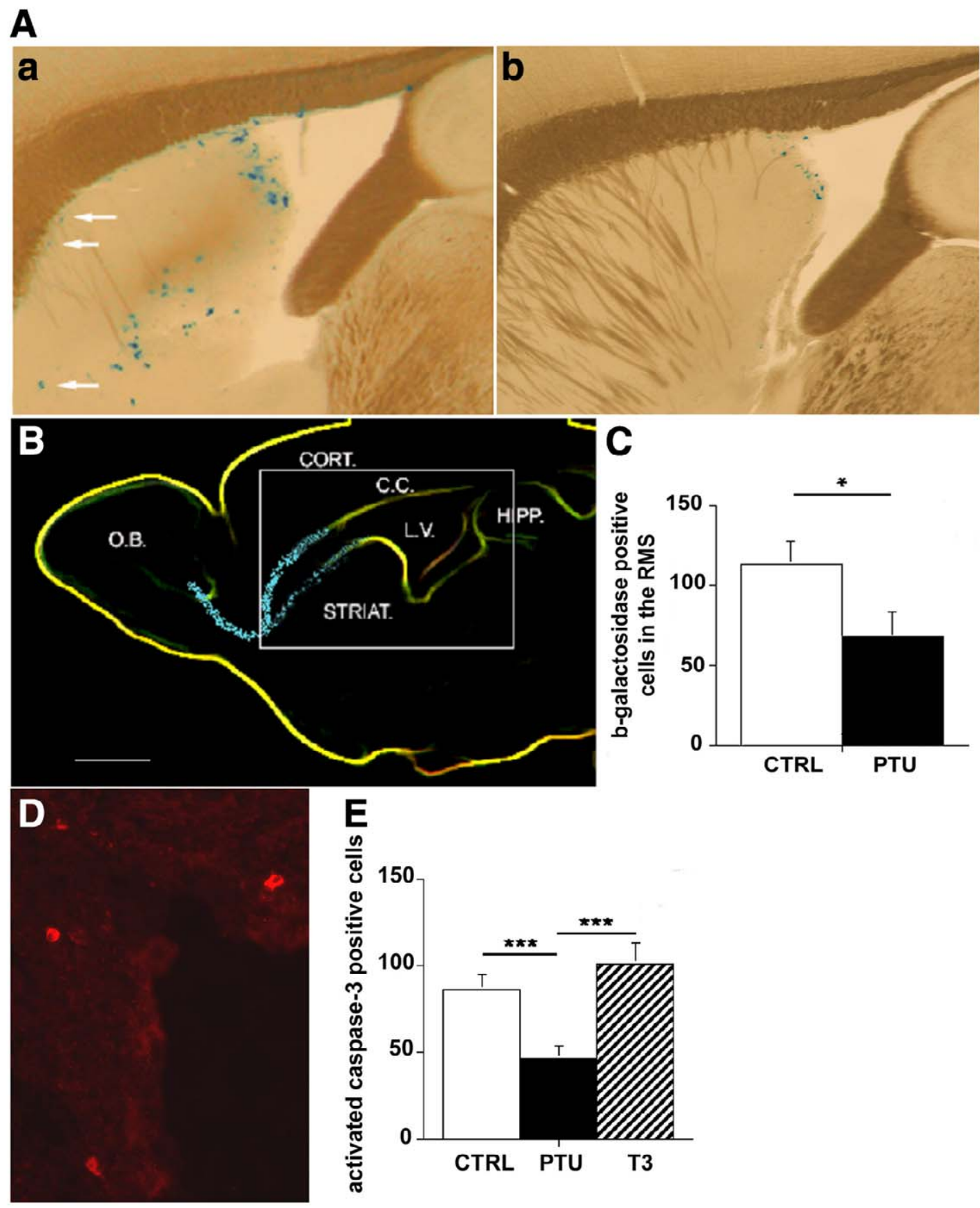

Figure 3. Hypothyroidism decreases numbers of genetically labelled cells entering the rostral migratory stream (RMS) and numbers of cells undergoing apoptosis. $A-C$ ) $p C M V$-lac-Z complexed with PEI was transfected by intraventricular injection in hypothyroid or control mice. $\beta$-Galactosidase-expressing cells in the RMS were quantified 1 wk later. A) Groups of positive cells are found around the ventricle or migrating via two routes (ventral and dorsal) in the RMS toward the olfactory bulb in euthyroid animals $(\boldsymbol{a})$ but are mainly limited to tarea around the ventricles in hypothyroid mice $(\boldsymbol{b})$. Bar: $500 \mu \mathrm{m}$. B) Schematic representation of a sagittal section of the adult mouse brain showing the lac- $Z$ positive cells migrating in the RMS. The limits of the brain and the main internal structures are indicated in yellow. Blue dots represent observed streams of migrating $\beta$-galactosidase positive cells (nonquantitative drawing). Bar: $1 \mathrm{~mm} . \boldsymbol{C}$ ) Hypothyroidism reduced numbers of positive cells entering the RMS $(* P<0.05)$. D) Active capsase-3 immunocytochemistry shows frequent apoptotic cells in a single section of the SVZ. Positive cells were counted from 0.8 to $1.2 \mathrm{~mm}$ anterior to bregma for each animal. Bar: $40 \mu \mathrm{m}$. E) PTU treatment significantly reduced numbers of activated caspase-3 positive cells. 
Fig. 4

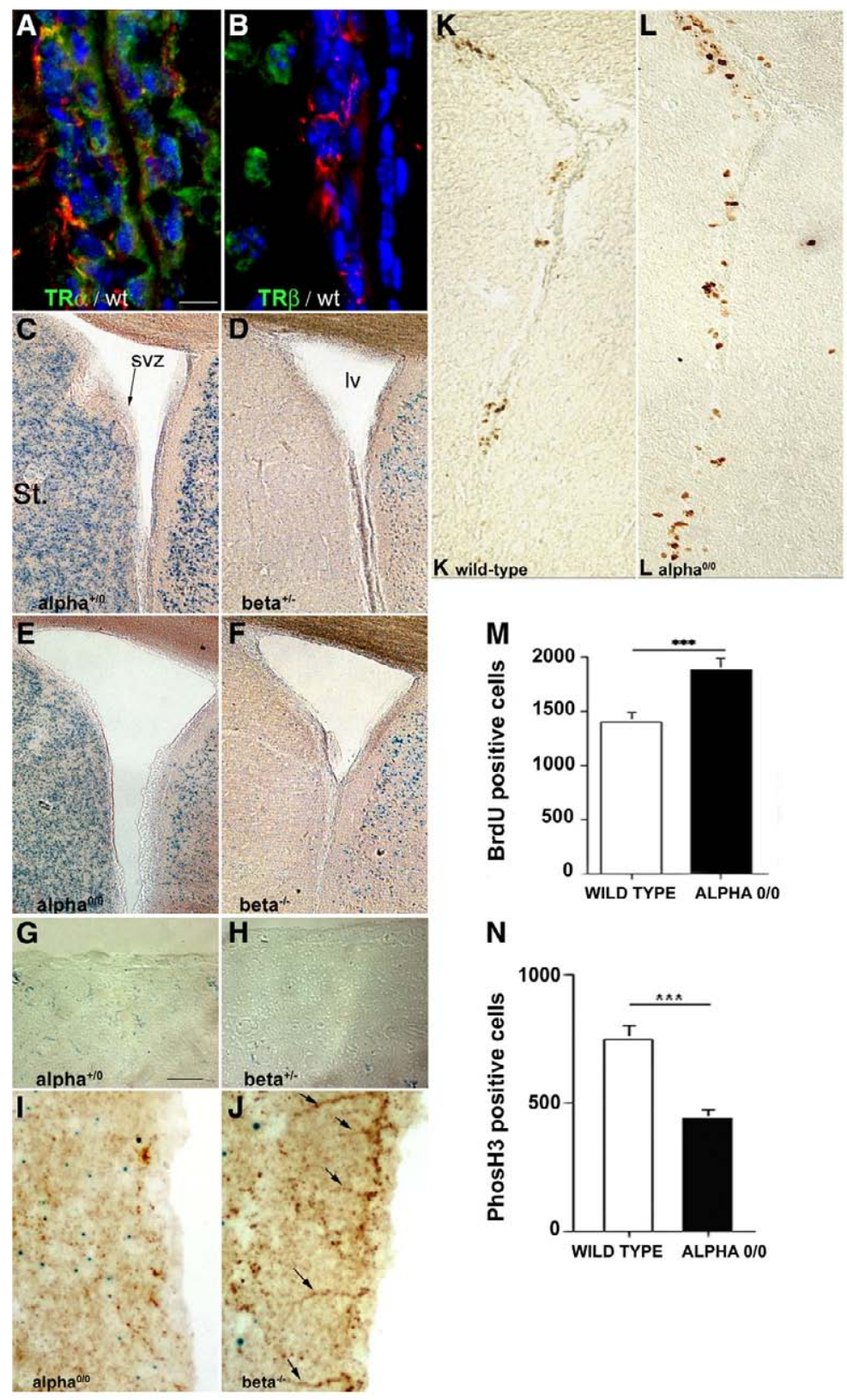

Figure 4. TR $\alpha$, but not $T R \beta$, is expressed and colocalized with nestin in the $S V Z$ and is required for normal progression of NSC through mitosis. $A, B$ ) Deconvolution microscopy and immocytochemistry on wild-type mice SVZ reveal specifically TR $\alpha 1(\boldsymbol{A})$ and TR $\beta(\boldsymbol{B})$. TR are labeled green, nestin red, and nuclei blue. Bar: $20 \mu \mathrm{m} . \boldsymbol{C}-\boldsymbol{F}) \beta$ galactosidase histochemistry (vibratome sections) reveals $\operatorname{TR} \alpha(\boldsymbol{C}, \boldsymbol{E})$ or $T R \beta(\boldsymbol{D}, \boldsymbol{F})$ expressing nuclei in mutant heterozygous mice: $T R \alpha^{+/ 0}(\boldsymbol{C})$ and $T R \beta^{+-}(\boldsymbol{D})$ and homozygous mice $T R \alpha^{Q / 0}(\boldsymbol{E})$ and $T R \beta^{--}(\boldsymbol{F})$. Bar: $\left.200 \mu \mathrm{m} . \boldsymbol{G}, \boldsymbol{H}\right)$ Semithin sections $(1 \mu \mathrm{m})$ of the SVZ of $T R \alpha^{+/ o}$ and $T R \beta^{+-}$mutant mice. Positive $\beta$-galactosidase cells are observed in the subependymal layer of the TR $\alpha$ heterozygous mice $(\boldsymbol{G})$ whereas expression of TR $\beta$ in TR $\beta$ heterozygous mice is not found in the sub-ependymal layer but is only seen more deeply in the striatum $(\mathrm{H})$. Bar: $6 \mu \mathrm{m} . \boldsymbol{I}, \boldsymbol{J})$ Nestin immunoreactivity and $\beta$-galactosidase staining in TR null mice. Note that nestin expression pattern is reduced and limited to the cell bodies in $T R \alpha^{/ / 0}$ mice but not in $T R \beta^{\prime-}$ where typical nestin-positive, long extensions are found (arrows). Bar: $20 \mu \mathrm{m} . \boldsymbol{K}, \boldsymbol{L}$ ) BrdU immunochemistry carried out after a 3 day BrdU treatment on $T R \alpha^{0 / 0}$ mice shows that $T R \alpha$ absence $(\boldsymbol{L})$ increases DNA synthesis compared with wild type controls $(\boldsymbol{K})$. Bar: $150 \mu \mathrm{m} . \boldsymbol{M})$ Quantification of the number of BrdU-labeled cells shows a significant increase in $T R \alpha^{0 / 0}$ mice $(P<0.001)$. $N$ ) PhosH3 immunochemistry shows that absence of $T R \alpha$ results in a significant $(P>0.001)$ decrease in the number of mitotic cells in the SVZ. 
Fig. 5

A

B
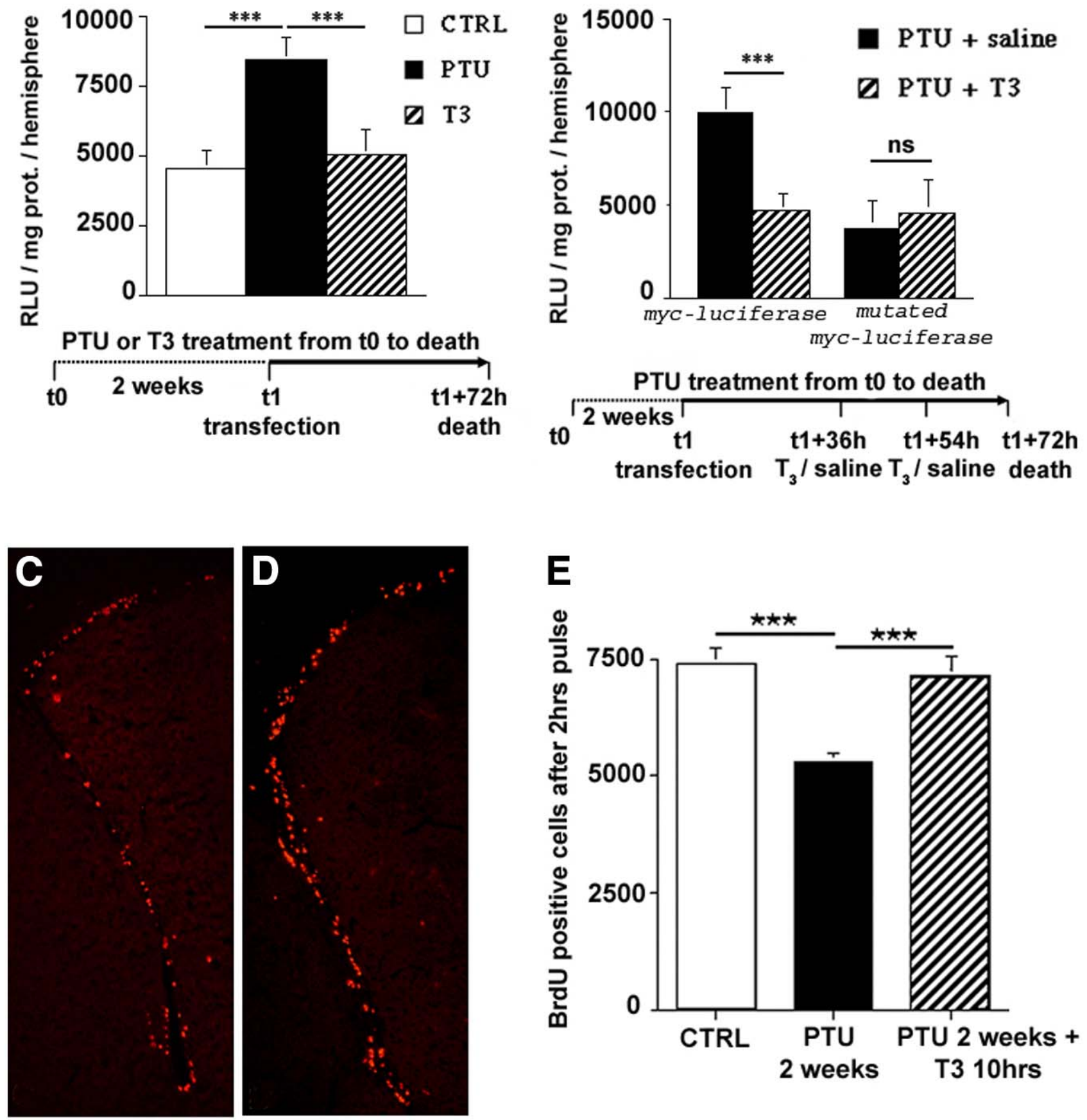

Figure 5. $\mathrm{T}_{3}$ treatment directly represses transcription from the TRE containing $c$-myc promoter in NSC cells in vivo and rapidly reduces the number of cells synthesizing DNA in the SVZ $\boldsymbol{A}, \boldsymbol{B}, \boldsymbol{B})$ Plasmid c-myc-luciferase $(0.1 \mu \mathrm{g})$ complexed with PEI was transfected into the NSC population and progenitors of the SVZ by intraventricular injection. Animals were treated with PTU for 2 wk prior to transfection and with $\mathrm{T}_{3}$ for either 3 days $(\boldsymbol{A})$ or $36 \mathrm{~h}(\boldsymbol{B})$ before death. After PTU treatment, luciferase expression was significantly higher $(* * * P<0.001)$ than that observed in $\mathrm{T}_{3}$ treated or control animals. No effect of $\mathrm{T}_{3}$ was seen on the $c$-myc promoter in which the TRE had been mutated (B, right pair of columns). Means \pm SE are given; $n=6$ animals per group. $\boldsymbol{C}-\boldsymbol{E}$ ) BrdU incorporation after a $2 \mathrm{~h}$ pulse of BrdU in hypothyroid $(\boldsymbol{C})$ or hypothyroid animals treated with $\mathrm{T}_{3}$ for $10 \mathrm{~h}(\boldsymbol{D})$. Note that a $10 \mathrm{~h} \mathrm{~T}_{3}$ treatment restores the number of cells synthesizing DNA to levels of control, nontreated animals $(\boldsymbol{E})$. 